\title{
Two Personalities of Comparative Literary Studies (Claudio Guillén and Dionýz Ďurišin) ${ }^{1}$
}

\author{
LADISLAV FRANEK
}

\begin{abstract}
The study aims to analyze two different conceptualizations of comparative literary studies - one by a Spanish scholar (Claudio Guillén) and the other by a Slovak one (Dionýz Durišin). It focuses on the circumstances of development of this discipline on the basis of particular sources and impulses with regard to the geographic limits of the study.

In the first part, the notion of supra-nationality is characterized as an effort to free oneself from the narrow frame of national literary history. Guillén was very aware of the tension between the local and the universal, or the particular and the general, which, according to him, requires the scholar to transcend conventional approaches and respect the reader's ordinary experience. Instead of a rigid critical frame, what is needed is a historical and critical horizon that does not exclude the individual dimension, nor a unifying perspective. At the same time, Guillén emphasizes the search for the universal dimension of literature. Guillén is sceptical about the focus on formal-linguistic approaches in studying literary development, which he observes at Spanish universities today.

On the other hand, Slovak comparative literary studies had different points of departure. The Slovak comparatist Ďurišin took many impulses from the Russian formalists, who focused particularly on the issues of the national literary development. As an example, the study uses the term historical poetics, applied in the study of the development of Slovak verse (Mikulás Bakoš). Instead of the prevalent genetic method used by Guillén, Durišin at the same time used a theoretical-developmental model in studying the relationship between national and world literature, with an emphasis on the role of the receiving literature.
\end{abstract}

Keywords: comparative literary studies, historical-critical approach, literary theory, genetic-contact method, Russian formalism, receiving literature, universalism, national literature/world literature

1 Translated by Miroslav Bázlik.

DOI: http://dx.doi.org/10.12697/IL.2014.19.2.1 


\section{Introduction}

It is important to bear in mind the fact that the area of comparative research of literatures offers an unlimited spectrum of theoretical and methodological points of departure, which can be perceived as a natural basis of exploratory work and of the needs to find adequate justification for the mutually conditioned approaches or procedures. The development of this discipline is therefore dependent on the enforcement of several factors having the nature of partiality and simultaneously of complementarity. In this light we can hardly evade the welcome requirement to analyze various methods in getting acquainted with the literary phenomena, their determining function from the perspective of the geographical affiliation of the individual explorers, and their specific contribution to creating the contents proper of the comparisonoriented projects.

It is obvious that the contemporary situation in the research of this problem area, in many aspects mirroring a crisis in the discipline, poses a question of whether it is possible to adequately return to the heritage of the previous conceptualizations or knowledge marked in each case by variability or by an inherent span of emerging aspects. If, in this connection, there is a repeated indication of the problematic or problem-suggesting nature of comparative work, there is a need to emphasize that it is in the poetic discipline where we find manifested a high amount of indefiniteness, incompleteness of elaboration, or relative openness towards the actual purpose of comparative research.

Let us add that the central objective remains unchangeable and more-orless binding: it rests on the primordial regard of literature, its specific mission, in many respects different from the influence of other, strictly or prevailingly scientifically formulated, disciplines (linguistics, natural and technical sciences, etc.). The result is a certain tension arising between the need of a system as a basic element of comparative work and the proper nature of the examined material, which is artistically unique and unrepeatable throughout history. It will not, therefore, be uninteresting to follow, at least in a few aspects, the interconnection of these elements, i.e. the fact of how the mentioned tension is dealt with by two outstanding personalities in comparative literature studies - Claudio Guillén, a Spanish scholar, and Dionýz Ďurišin, the as yet most highly acknowledged Slovak representative of this type of research. 


\section{Claudio Guillén}

As far as the theoretical and methodological ideal impersonated in the works of Guillén is concerned, one of its main features is a consistent enforcement of the concept of supra-nationalism, which, in the $2^{\text {nd }}$ half of the $20^{\text {th }}$ century, would have enabled to overcome the traditional orientation of comparative studies as regards the national aspects of literary research. In the second edition of his most significant work Entre lo uno y lo diverso. Introducción a la Literatura Comparada (Ayer y hoy) (Between the One and the Diverse. Introduction into Comparative Literature (Yesterday and Today)), published in 2005, Guillén returns to the postulates of his long-lasting previous exploration. Bearing this in mind, the Spanish explorer approaches not only the latest results of research activities but also wants to point to the crisis of comparative literature, manifested mainly in the educational process at Spanish universities. He finds support for his critical arguments in his own experience in dealing with comparative themes, with the sensitively elaborated theory of cross-literary relations standing at the point of intersection of various components of this discipline.

Guillén, as a comparative scholar, forms his view on the basis of the awareness of certain tensions between the local and the universal, or between the specific and the general. If he avoids the concept of nation or nationality, he obviously takes into account the overuse of these concepts in the past; he sees them as extreme concepts containing a number of general oppositions applicable to various situations. Therefore he sides with the circumstances which bring to the foreground the role of the reader and simultaneously of the critic in relation to the world or worlds, between the present and the nonpresent, between experience and significance (Guillén 2005: 29).

The point is, therefore, in capturing the common experience of a writer, especially a poet, who in the everyday perception of the world searches for a flash of "otherness" as a stimulus directed towards other places, towards other worlds. This is the sense in which we should understand his reference to the opinions of the Mexican poet and thinker Octavio Paz, who in an article published in 1983 in Madrid's daily El País, says: "The art cannot be reduced to the earth, nation, and the moment which create it, but nevertheless are inseparably connected with them [...] A work is the form growing from the earth and not occupying space: it is an image." (ib.) However, this finding, in Guillén's view, does not provide a sufficient reason which would lead to the impossibility of exploring the circumstances of the creation of a work of art. That requires constant overcoming of the established attitudes of the observer: of fundamental nature is the material contribution of history or of the concept 
of literature, several classes and categories, which have not been purely national. By way of example, he presents the centuries-old genre of comedy, the nonsubstitutable means based on rhyme, but also the world-wide movement called Romanticism. In order to investigate these concepts, he lays emphasis on their supra-national character, which he finds more appropriate than the concept of international, applicable to a large extent in nationally-oriented observations. The concept of comparative literature, therefore, in the spirit of the humanistic aims of the fundamentally anchored discipline is perceived by Guillén as an instance of enthusiasm, project or activity different form other activities.

Referring to Goethe's dream of conceiving of an act of literary creation as "literature of the world", he is interested in not-exclusively social, or political, revealing of the properties of literary communication, its primary sources, and metamorphosis of the species, forms and themes. Such ideas about the role of the comparativist are developed in practically all the chapters of his book, in which he introduces a number of examples of mutually enriching communication between various creative personalities of the past. For example concerning the influence of Montaigne and Plutarch on Shakespeare's verse model, and even the supra-national inspiration of Pan-Slavism in Ján Kollár's sonnet sequence Slávy dcéra (The daughter of Sláva, 1824), which were born in the environment of other, Hungarian- or German-speaking, communities.

The most proper sense of all the above findings on the basis of well-aimed references is to reach a preliminary model of comparative activity, which does not emanate from a previously strictly set framework, but from a historical and simultaneously critical horizon. The interplay of these two views is, in Guillén's opinion, a prerequisite of modern culture, the theme of final reflection. The absence of a more exact framework simultaneously indicates the reader's legitimate participation, the openness of approach to literary dialogue taking place also outside the theoretical view of the comparativist. This is the starting point of the free discussion aimed at the hypothetical relation between the local and the universal, or, in other words, between monism and pluralism (ib. 37).

In Guillén's conception, literary history and literary criticism merge to form an inseparable pair. Such an approach leads the Spanish scholar toward an at least approximate definition of the comparative work having its own character and specific procedures. In the given context, he also emphasizes the integrating nature, the emotionally conditioned efforts of comparative research. As he finds the most appropriate comparison in the internal foundation of poetic creation, in the historically most straightforward manifestations of universality, his model represents a highly varied and simultaneously individually variegated attempt at defining the comparative discipline as an autonomous, in many respects independent one: the poetry researcher, he says, must not and should 
FRANEK

not be confused with the attitude of either the scientist or the philosopher, especially as far as the temporal and individual dimensions of his object of research are concerned.

In his opinion, comparative literature has undoubtedly been a historical discipline and responsible comparativists deem any supra-historical or intrahistorical premise as premature, useless, or unacceptable. Apart from that any attitude within the line of idealism - whether Neo-Kantian or NeoPlatonic - which disregards individual differences, appearances, or surfaces of things, irreversibly fights against the criticism of individual arts: painting, architecture, music, ballet, cinematography. In these areas of culture it would be absurd to overlook the unusual plasticity, vivid realization, sensorial and sensual impression, without which a work of art gets distorted and lost (ib. 39).

The aim of comparative activity follows from the dialectic, from an everlasting awareness of the problem. It is this process of getting to know the dialectic relations which leads to a gradual enrichment by its constituting elements. We are repeatedly concerned with projecting, with a desire which in the present moment reacts to a set of the most characteristic problems. Thanks to that, in his opinion, not everything has a nature of individuality, but gets created as a universal dimension and component of literary history, which is subject to incessant rebirth and changes. Unlike the strictly required principles, clearly defined aims, it is first of all a process requiring to formulate a working hypothesis directed at its confirmation, the analysis involving a large amount of wisdom, going far behind today's state of knowledge. We thus have to do again with the desire, which at the present moment reacts to a set of the most characteristic problems. Thanks to that, in his opinion, not everything has a feature of individuality, but is formed as a universal dimension and component of literary history subject to incessant rebirth and changes. Contrary to strictly demanded principles, clearly formulated aims, it is, first of all, a process.

This effort is also marked by surmounting the original idea of French comparativist Paul Van Tieghem, author of the first manual of the new discipline (La Littérature comparée, 1931), whose central principle is the study of international literary influences. It is obvious that the penetration into the exchange of literary values alone, as is also elucidated by the preceding lines, must allow for many obstacles in the reception of the original work of literature in a different environment. In this motion, naturally, there arises a certain tension provoked by a clash of various aesthetic and ideological values, which extraordinarily complicates the mode of comparison, since, as French comparativist Daniel-Henri Pageaux (La littérature générale et comparée, 1994) puts it, it brings into the foreground the moment of difference given by the traditions of the literatures compared. 
At the same moment a whole set of external factors come into play, which are connected with the overall historical, social and political development. The special character of literary elaboration, on the other hand, opens the space in order to weaken the causal determination of the above factors emphasizing the primordial role of national literatures. In the given question Guillén depends on the statement of the Spanish writer and theoretician Dámas Alonso.

Alongside literary history and literary criticism, which have a central place in Guillén's thinking, it is impossible, of course, to overlook another element which comparative literature should not dispense with, namely the conceptual area belonging to the terminology of general literature. It is typical that while following the developmental aspects of literature from the viewpoint of periods, types, or styles, Guillén denies the zero stage of theoreticality, i.e. "innocent" perception of inter-relations founded on preliminary concepts, mental habits or expectations, e.g. in the recent fast development of North American comparative studies, mostly laying a emphasis on formal linguistic discharges.

Certainly he sees in it a withdrawal from the humanistic content of his discipline, since such an approach emphasizes the specific regard of the mission of literature. In his own research of picaresque literature, Guillén takes as his starting point the vision of approximate induction, not binding and neutrally normative, but rather determining certain general qualities capable of leading to particular results (ib. 93). Guillén, therefore, continually remembers the first-rank place of empirical research considering also the reader, his perception from observation. After all, this finding is the basis for all of his argumentation concerning a marked weakening of comparative literature in the curricula of contemporary Spanish universities. In the introduction to the $2^{\text {nd }}$ edition of the book Between The One and the Diverse, Guillén comes to the straightforward conclusion that the loss of the original independence of this discipline follows from the fact that in Spain comparative literature has been "consumed" by the theory of literature. It must be said that mainly in the 1980s, after years of professional growth in France and in the U.S.A., after being a visiting professor in Germany and later at Princeton, San Diego and Harvard, and eventually after returning to Spain in 1989, when he was professor at Universidad Autónoma and Universidad de Pompeu Fabra in Barcelona, Guillén became fully involved in fighting for the official recognition of comparative literature as an independent pedagogical discipline at the university. He was led by his persuasion that it was mainly the Hispanic world, i.e. not only Spain but also Latin America, which met all the necessary requirements for being able to successfully develop the living nucleus of this discipline. He sees as the main reason for the deplorable situation caused by the non-organic joining of the 
two disciplines - the theory of literature and comparative literature - into one discipline of study the superiority of political aspects over cultural ones. Its aftermath is the decomposition and non-differentiation of knowledge, the supremacy of textological analyses without a precise delimitation of the concepts. The globalization pressure, centred on the fight for equal rights of ethnic groups, makes this process gradually transform itself into an indifferent attitude to literature itself.

A concomitant feature is the fact that cultural studies include in their programme an outwardly "open" approach to various forms of cultural manifestations (urban development, press, fashion, radio, advertising, etc.), as a result of which we are losing the influence of the major literature, of our acquaintance with its nature, values, historical distinctiveness, critical attitude towards reality, i.e. everything in which literature has had, from times immemorial, an irreplaceable position. As a counterbalance to this process of integration, Guillén gives examples from modern literature. In the works of E.W. Said, formed in Harvard's Department of Comparative Literature, he discovers those signs of writing which he has always perceived as fundamentally close. In his spacious theoretical reflection styled Beginnings (1975) he underlines the author's critical view of the Palestinian expatriate, the role of the $20^{\text {th }}$-century artist and intellectual depicted as an unstable, absent-minded person roaming, for political reasons, from place to place, a man of many faces, a split personality. While in his next book Culture and Imperialism (1993) Said presents the problem of the declared European hegemony, the problem of tensions and decisions faced by the liberated, formerly colonized countries, after 1914, together with the analysis of the thinking of the inhabitants or the literary imagination in Africa, India, or the Caribbean, he always bears in mind his independent view of the external framework of the events.

On the background of history and economics, as Guillén concludes, Said's work does not lack even a self-critical attitude, "contrapuntal thinking", the ability to encompassin the complexity of the problems also the individual artistic and human values of prominent writers (Flaubert, Camus, Dickens), in whose work Said looks for the necessary inspirational sources, his model. We have therefore to do with facts which, according to the Spanish scholar, are stripped of simplifications, since their deepest spring is the multicultural nature of the peoples, the pronouncement of an ethically valuable and convincing literary attitude. In the mentioned example, too, the main intention is to overcome the intellectual and political borders, the awareness of the impossibility of linking oneself to any preset or constant scheme, thanks to the all-encompassing moral creed. 
As a consistent advocate of the special mission of literature, Guillén, by way of similar analyses oriented at the role of the creative individual throughout history, is continually aware of the non-negligible position of the comparative forms of research. As to the overall summing-up of the various approaches, he emphasizes the existence of various points of view, which determine the method of exploration and its multifariousness. In the spirit of the central concept of supra-nationality, he tries to briefly sketch its main models.

The first model contains genetic contacts and other relations between authors and processes belonging into various national areas, or the common cultural points of departure. As an example he mentions the picaresque literature and the theme of Don Juan. The conceptual framework lies in the search for common features and the general and special manifestations according to historical criteria, e.g. in analyzing the tragedy, elegy, melodrama or free verse. In the second model, emphasis is laid on generic independence of civilizations as a result of their socio-historical and economic conditions. Thanks to that in the search for common characteristics the external framework comes to the foreground, which enables to connect and compare these phenomena according to their national and civilization differentiation, e.g. in connection with the development of the novel in the $18^{\text {th }}$ century, conditioned by the rise of a new social class, the bourgeoisie. In the third model the concept of supranationality is applied in keeping with the principles and postulates following from literary theory. As he states, the degree of theoreticity in this particular research is the highest. Its presentation is offered by the existing theoretical framework.

As a result of modern theoretical findings it is impossible to exclude in the observation a view of the developmental processes based on periodology, the birth of modern literary genres or styles, e.g. in accordance with Barthes's conceptualization of the "zero degree" of style (ib. 97) that enables a fruitful confrontation of various theoretical models originating from various civilizations and their application in the research of the east-west relations. A precious addition to the historical critical basis of comparative literature is, therefore, the possibility for the dialogue between unity and differentiation to run as far as possible in accordance with theoretical knowledge. Simultaneously it may also happen that - as he claims - the new knowledge may put a theoretical concept in doubt. In spite of that Guillén admits that this third model has recently undergone unprecedented development and provides suitable theoretical points of departure for comparative research of literatures. This concerns the Spanish universities as well, in which new space is open for the mutual enrichment of various approaches, though this process in many respects suppresses the aims of comparative research. 
FRANEK

\section{Dionýz Ďurišin}

In this connection Guillén comments on the significant contribution of the Slovak scholar Dionýz Durišin (1929-1997), who in his book Porovnávací výskum literatúr (Comparative Research of Literatures, in the German edition Vergleichende Literaturforschung, 1972) justifiably considers this double working co-relation as a shared future as he remembers the concept of historical poetics from the late $19^{\text {th }}$ century, which was demanded by Alexander Veselovski (Ďurišin 1972: 109). However, he does not fail to emphasize that the Russian scholar's conception gives room to the inductive method ("clarification of the essence of poetry through its history") in contrast with the research and findings oriented at a wider relation between history and theory, which, according to him, gives a full viability to the third model.

There is no doubt that Guillén's above assertion reflects the basic problem of the differences contained in comparative research of literatures with regard to its methodological diversity given by different geographical circumstances of modern development. It may be worth mentioning that Guillén's conceptualization temporally overlaps in this direction with the results of Durišin's original theoretical reasoning (in this place I will deliberately ignore the later stage of his scientific development directed, in my opinion, at a wide and abstract area of interliterary communities), thanks to which it is possible to subject both approaches to an interesting mutual confrontation. If Guillén's views of the research model of theoretical orientation accommodate the concept of historical poetics, it means that the Slovak situation allows for emphasizing a different understanding, especially as to the working points of departure and, actually, the overall conceptual means of the research. It must be stressed that the prevailing historical-critical model of the Spanish scholar, as follows from prior analysis, availed itself in Slovakia of a different nature of sources and stimuli. In the true sense of the word we can speak of the scientific, theoretically stricter and more elaborated model. In the beginning, first of all, we are faced with the finding that during the course of the rise of comparative works planned in this way Slovakia sees a fundamental reevaluation of the traditional approaches in an effort to overcome the isolationism of the former periods.

One of the welcome changes presented by Durišin is the indispensability of entering more intensively in confrontation with the results of West European countries. Referring to the book by the French scholar René Étiemble Comparaison n'est pas raison. La crise de la littérature comparée (1963), Ďurišin mentions the moment of a certain stagnation, or crisis, seeing as its main reason the lack of clarity in the methodological questions of literary research (Durišin 1975: 16). On the other hand, he mentions a wide practice, many stimuli from 
the area of material knowledge, e.g. in the works of Pichois, Rousseau, or Weinstein (there is no mention of Guillén in his most important programmedefining book Theory of Literary Comparison).

The basic requirement characterizing Durišin's conceptualization of comparative literature is the reevaluation of the traditionally understood literary history. This is connected with the narrow platform, the partiality of research directed mainly at capturing the "intra-literary" or "supra-national" literary process. This has led, in his view, to a neglect of the wider relationships and connections, not only in relation to larger wholes, such as the national literature, but also within the framework of the intra-literary process itself (ib. 10). In that sense we have to do with the recognition of the wider regularities of world literature. In the past, he says, the questions arising in historical exploration of literature were marked with a first-rank regard of the literary, literary and social, political, or national needs. Therefore the primary task was to search for such systems, concepts or points of departure, which would have the ability to bring the examined phenomena to the level of mutual relations and connections, both from the viewpoint of the internal development of literature, as well as in the sense of overstepping the narrow framework, in the direction to revealing the nature and regularity of word literature.

This necessity is signaled by the fact that in contrast to Guillén, Ďurišin advocates, as far as possible, an exactly formulated scientific model, which for its realization presupposes the enforcement of the concept of predictability, whether regarding the intra-literary development or its spreading to the supranational horizon of comparative research. This process is marked by a weakening of the genetic-contact basis of traditional literary historiography by way of increased attention to the material system of the phenomenon followed. In domestic relations Durišin thus reacts to the fact that comparative research has not constituted independently on the background of Slovak literary studies, which was inevitably connected with specific tasks of research into Slovak literary history (ib. 22). He observes a different situation, e,g, in Bohemia (Polívka, Machál, Horák, Wollman), in Poland (Markiewicz), or in Germany. The result was a few sporadic studies, organically contributing to the knowledge of the Slovak literary process within the framework of Slavic literatures - in the beginning, as he states, there were the works of Pavel Jozef Šafárik - Geschichte der Slawischen Sprache und Literatur (History of Slavic Language and Literature), and Ján Kollár - O literárnej vzájemnosti mezi kmeny a náreč́mi slavskými (On the Mutual Literary Affinities among Slavic Tribes and Dialects). The task of these works was to confirm a separate place of Slovak literature, its autonomy, of which the witnesses are, says Durišin, the works written by Štúr, Kalinčiak, Vajanský, Škultéty and others. 
In this area a significant place is occupied, first of all, by the stimulating nature of the Soviet literary studies, which, in the course of a few decades, provided a heterogeneous field of theoretical knowledge. Thanks to it, the developmental dynamics of literature, its procedural character was stressed. The prerequisite was the extension of the traditional concept of literary history by the concept of historical poetics, whose task, from the early stages of research, in accordance with the principles of the artistic avant-garde to direct the attention at the connection between theory of literature and its development, which found its reflection, in the first place, in following the Russian national literature.

In this sense - as is well known - a piece of pioneering work was done by Mikuláš Bakoš, who as early as the 1930s systematically dedicated himself to the study of the works of the Russian formalists. He also participated, directly and through his own translations, in their promotion in our academic circles (two editions of The Theory of Literature, A Selection from the Formal Method, 1940, 1971.)

In contrast to traditional literary history, the Russian formalists strongly accented the linguistic nature of poetry research. Of primary importance became the effort to fathom the internal laws of poetic art, to bring to attention the structure or building principles of its functioning, to see in poetic works mainly the literary fact offering itself for mutual, objectively provable and verifiable investigation, as far as possible. The dialectic focusing of the formal method in following the developmental questions of poetry were utilized by Bakoš in his actual analyses in the book Vývin slovenského verša od školy Štúrovej (Development of the Slovak Verse since Šturr's School, 1939, 1949, 1966). His subject of research was the variability of the poetic function and its utilization in the individual phases of the development of Slovak poetry in comparison with the procedural understanding and subjective perception of literature in contrast to Guillén, whose aim was to respect the genetic-historical points of departure on the whole, disregarding a priori fixed principles and norms. The Slovak comparative literature research, in the spirit of the postulates of Slovak literary studies, has followed, thanks to Durišin, the principles of system-oriented research supported by statistical data and concrete material. It is worth mentioning that Bakoš fulfilled this requirement completely while following the binary oppositions in the form, in the language, and in the structure of Slovak verse, and under the Czech scholar Jan Mukařovskýs influence, he understood the opposition between the metric structure and the syntactic articulation. With all these stimuli he managed to revive the discipline of theoretical and historical metrics and to erect it on the logicalrational systemically functioning foundations. 
It is typical that a similar ambition - "the act of correlation defining the relationships” - manifested itself also in Durišin's later thinking. The essence of this problem is connected with the logical aspect of the scientific style of comparative analyses, whose main aim is to start from a precisely formulated project. After all, this postulate, too, in many respects contradicts Guillén's conception of comparative literature (not comparative literary studies or "comparatistics", as this discipline is perceived, in a strictly scientific spirit by Durišin) since the historical-critical model in the light of the Spanish comprativist reckons with the theoretical generalizations according to how the primary genetic content of the universal, personally expressed or modeled creed of writers enables to search for the common signs of cultural-civilization processes, e.g. in researching picaresque literature.

I think that this is where it is necessary to see the basic conditioning as far as the difference between the two attitudes is concerned: whereas Guillén made an effort from the very beginning to perceive comparative literature with regard to the specific position of literature, viewing literature as an area of intensive theoretical, independent preparation, to his approach Durišin could, with regard to the basic points of departure, express a skeptic standpoint. If we give a deeper thought to the logical explanation, what will appear as an uncontestable fact is that the primary place of theoretical models becomes a substantial obstacle in the comparative research of a humanistic orientation, since it does not enable us to build on Guillénian, pre-perceived "openness" of the scholar's view, the focus of which is the writer and together with him his integrally natural, "non-scientific" partner - the reader. Though Durišin does not deny that comparative literature is contained in literary history and forms its organic part, in contrast to Guillén, who pays attention to the specific and irreplaceable mission of literature, however, he cannot but claim that in this connection we cannot speak about a specifically independent discipline of literary studies, but only about working procedures of investigation, which are internally connected with its methodology (ib. 72).

With regard to emphasizing the methodology, which through its program orientation gives preference to qualitatively different perspectives, the traditional conceptualization of comparative literature is considered, in his case, as obsolete, i.e. it does not provide the right to see in comparative studies a specific discipline. Nevertheless, the threat of this discipline becoming extinct spoken about by several contemporary comparativists (e.g. Spivak) still provides the possibility of calling attention to the voices emphasizing the exaggerated neutralization of modern theoretical approaches and procedures, many a time aloof from the real nature of the literary work, a onesided requirement to identify oneself with the literary phenomenon through 
searching and describing its general or generalized symptoms. We have to bear in mind that the mentioned threat is analogically perceived by the Spanish scholar even in spite of the fact that in some questions the working procedures and criteria exhibit, in comparison to Ďurišin, similar and related features.

Actually, this concerns also the so-much discussed concept of influence, which both comparativists very often criticize from the position of the dialectic, anti-positivist model of research. We feel it necessary to express the opinion that for the Slovak comparativist, scientifically submerged in processes, the typological essence of literature occupies a more radical standpoint than for his Spanish counterpart. It is connected, on the one hand, with his emphasis on the relatively static relation national literature - world literature, and, on the other hand, with the fact that Durišin who vehemently spoke on this topic expressing the rare need to respect, against the background of this relationship, the role of the receiving literature, could no more depend so much on the idea-thematic variable, and therefore the uniquely specific nucleus of literary art. It will not, therefore, be useless to claim that averting an emerging threat has its natural roots in the fact that even despite several positive features of literary research (Durišin does not lose, in contrast to Guillén, a wider aspect of uniqueness of the developmental row), literature should, in my opinion, remain protected from the undifferentiated, too much dispersed, or, on the other hand, mostly closed character of the theoretical model or models. These actually function as a necessary propaedeutic preparation drawing from theoretical programming aspects of literary history (literary genres, the study of figures and tropes, prosodic features in languages, etc.), which have had in the conditions of the development of national literatures, from times immemorial, a specific mode of self-realization, including the extraordinarily varied subsoil of the individual authors' poetics born in the universal space of their mutual stimulation, within the horizon of the supranational exchange of literary values, directed particularly in our time to an unusual variability and simultaneously synthesis (cf. the genre of literary fantasy, magical realism or the "real miraculous" as it can be seen mainly in modern and postmodern Hispano-American literature). Thanks to crossing the borders of national literature, the concepts of literature and artistic creation thus get reevaluated from various points of view, in a harmony of components of linguistic and cultural expression.

Taking into consideration the methodological aspect or problem of Durišin's theoretical and practically registered thinking, we cannot deny that the Slovak comparativist failed to realize these limitations or shortcomings in his time or did not predict them. For example, in connection with the theory of literary communication, built on the specific relation between the language of communication and poetical language, he states the progression 
of the individual adherents of the Russian formal method. The functionality in following the constructional laws of the work of literature emphasized by Shklovskij in his article "Art as Procedure" is welcome by Durišin in the sense of revealing the genesis of motifs and sujet-building with the help of the comparative confrontation of phenomena.

The dynamic principle of automatization and innovation of artistic means, from which essentially originated the theories of the formalists, enabling to productively penetrate the linguistic-constructional nature of the literary facts, appeared to Durišin as incomplete, or, directly speaking, in a certain sense hermetically sealed. Getting to know the developmental dynamics of national literature required the coming to terms with the traditional understanding of literary history; the prevailing view of the development-innovation questions of national literature, however had not yet allowed to accede in a more complex way, to supra-national analysis.

Perhaps the most eloquent proof of it in Slovakia was Bakošs approach marked by a consistent perception of the logical aspect of the metrics and its internal laws. From this point of view, in studying the Slovak verse, his method, its development and theoretical issues, should even today be appreciated as an immensely valuable contribution for an objective, rich in material and statistically backed research. His findings form a part of the indispensable first phase of theoretical preparation (indisputably in the question of the differences in prosodic systems and the place of the Slovak language within their framework), which does not disregard the fact that poetic expression is influenced by historical and developmental conditions. There is no doubt that in comparison with Guillén's prevailing ontological-genetic conceptualization, the model is one which we will hardly meet in the conditions of the Spanish, or, from a wider perspective, West European development of comparative literature on such a basis. One of the few exceptions is undoubtedly the book by the French author Jean Cohen dealing with the verse theory (Structure du langage poétique, 1970), in which, however, in contrast to Bakoš, we can also systematically follow a wider figurative-metaphoric framework of verse composition against the background of the development of French poetry.

As I have noted in many a place in my cross-literary studies of the translation relations between Slovak and French poetry (Franek, Štýl prekladu - Style of Translation, 1997), a prerequisite for a more complex perception of the relation of Slovak literature to literatures of other nations is the need to abandon, to a certain extent, the formal-structural imperatives and utilize also the sensitive engagement of the researcher in comparative work. In other words, it means the approach to the historical-critical foundations of literatures, whose recent development is marked by an increasing overlapping especially on the level of 
FRANEK

the holistically perceived poetics should include various stimuli of national and foreign provenance. In line with this, once more, Goethe's dream of the "literature of the world" may materialize. The concept of national literature in relation to world literature, as proclaimed by Durišin, would acquire clearer contours by way of the awareness of their mutual interaction, of the often nontransparent, but simultaneously more attractive harmony of their regional and national character.

\section{Conclusion}

I have looked at two prominent personalities of European comparative literature, yet I cannot fail to mention in this place the fact that in Slovakia approaches to literature based on historical development and literary criticism have been, also in relation to others, seemingly more developed, nourished by a number of valuable, although in the first place not always comparatively oriented researches. Whether it be Jozef Felix's strong minded effort to free himself from the too narrow a framework of national literature by way of enthusiastically getting acquainted with the masterpieces of European and world literature, or Blahoslav Hečko's pioneering work directed at critical, many a time also theoretical penetration into all the corners of the translation trade (Dobrodružstvo prekladu - The Adventure of Translation, 1991), we can each time speak about a sensitive ambition to attain trustworthy findings. These have the ability to indirectly or, more vividly, even in contrast to Guillén or Ďurišin, take advantage of the valuable contribution of modern linguistics (Saussure, Hjelmslev), as Hečko's amd Felix's artistic procedures reflect a unique creative zest growing out of the direct constructive, or practical, contents of comparative activity.

From the interdisciplinary point of view, with a stress on the relevant theoretical preparation, including a thorough study of the developmental lines of literatures, there is an outstanding, and in my opinion rare, symbiosis in the critical-historical approaches from the pen of Anton Popovič. His model of historical poetics in studying the influence of Russian Romanticism on the Slovak Romanticism (Preklad a výraz - Translation and Expression, 1968), as well as several theoretical papers in relation to questions of prosody, open up once again the possibilities of the fruitful linking and also reevaluating of the previous models, not to mention the fact that in the present conditions the extensive inspirational properties of Guillén's and Durišin's works may be reflected, and in practice already are being reflected, also in the educational process at our universities. 
Two Personalities of Comparative Literary Studies

It is obvious that they have more liberty today to research the so far little studied areas in connection with the influence of West European and other literatures on the Slovak literature. From the present point of view it is possible to more reliably clarify in what ways the two worlds of Guillén and Durišin are related. Despite the fact that these two models are essentially different or limited, we cannot exclude in the future their multifarious influence on our discipline.

\author{
Ladislav Franek \\ Ladislav.Franek@savba.sk \\ 82107 Bratislava \\ Čiližská 10 \\ SLOVENSKO
}

\title{
Bibliography
}

Bakoš, M. 1966. Vývin slovenského verša od školy Štúrovej. 3. vyd. Bratislava: VSAV.

Bakoš, M. 1969. Literárna história a historická poetika. Bratislava: VSAV.

Bakoš, M., ed. 1971. Teória literatúry. Zostavil a preložil Mikuláš Bakoš. 2. vyd. Bratislava: Pravda.

Claudio Guillén, lecciones de un maestro. 2009. Madrid : Complutense.

Cohen, J.1970. Structure du langage poétique. Paris: Flammarion.

Ďurišin, D. 1967. Problémy literárnej komparatistiky. Bratislava: VSAV.

Durišin, D. 1975. Teória literárnej komparatistiky. Bratislava: Slovenský spisovatel'.

Durišin, D. a kol. 1991. Osobitné medziliterárne spoločenstvá 2. Bratislava : VEDA.

Ďurišin, D. 1995. Teória medziliterárneho procesu 1. Bratislava: ÚSL SAV.

Hečko, B. 1991. Dobrodružstvo prekladu. Bratislava: Slovenský spisovatel'.

Hjelmslev, L. 1968. Prolégomènes à une théorie du langage. Paris: Éd. de Minuit.

Felix, J. 1957. Cesty k vel'kým. Pohl'ady na európsku literatúru. Bratislava: Slovenské vydavatel'stvo krásnej literatúry.

Felix, J. 1970. Modernita súčasnosti. Bratislava: Slovenský spisovatel'.

Franek, L. 1997. Štýl prekladu. Vývinovo-teoretická a kritická analýza slovenských prekladov Paula Claudela. Bratislava: VEDA.

Franek, L. 2005. Modernita románskych jazykov. Bratislava: VEDA.

Franek, L. 2012: Interdisciplinárnost' v symbióze literárnej vedy a umenia. Bratislava: VEDA.

Guillén, C. 1998. Múltiples moradas. Barcelona : Ed. Marginales Tusquets.

Guillén, C. 2005. Entre lo uno y lo diverso. La Literatura Comparada (Ayer y hoy). Barcelona: Ed. Marginales Tusquets.

Pageaux, D.-H. 1994. La littérature générale et comparée. Paris: Armand Colin.

Paz, O. 1993. El Laberinto de la soledad. Madrid: Ed. Cátedra. 
FRANEK

Popovič, A. 1968. Preklad a výraz. Bratislava: VSAV.

Popovič, A. 1970. Štrukturalizmus v slovenskej vede (1931-1949). Martin: Matica slovenská.

Popovič, A. 1971. Poetika umeleckého prekladu. Bratislava: Tatran.

Popovič, A. 1972. Komunikačné projekty literárnej vedy. Nitra: Pedagogická fakulta v Nitre.

Saussure, F. de 1962. Cours de linguistique générale. Paris: Payot.

Vajdová, L. 2009. Sedem životov prekladu. Bratislava: VEDA. 